\title{
Research on the selection of leading industries in Beijing based on input-output analysis
}

\author{
Qianhong Li ${ }^{1, a}$ \\ ${ }^{1}$ School of economics and management, Harbin Engineering University, Harbin 150000, China \\ a786090695@qq.com
}

Keywords: leading industry; input-output analysis; Beijing; regional economy

\begin{abstract}
The correct selection of leading industries can promote the coordinated economic development of a region. This paper takes the input-output table of Beijing in 2012 as the basis, and carries out the research on the selection of leading industries in the region, by using the analysis method of input-output, which can provide a theoretical basis for the development of regional economy in Beijing, and put forward some suggestions.
\end{abstract}

\section{Introduction}

The input-output table reflects the relationship between input and output of various sectors of the national economy, which is the embodiment of the operation of the national economic system in a certain period. The input-output technique has been widely used in the field of production analysis, demand analysis, price and cost analysis, and energy and environmental analysis, and theoretical research is carried out in this paper on the selection of leading industries in Beijing, according to the input-output table of Beijing in 2012.

\section{Empirical analysis of leading industries in Beijing}

\section{Analysis of the comprehensive ability of industries}

The response coefficient,influence coefficient, technical coefficient, coefficient of economic benefit, coefficient of labor input structure and coefficient of industrial expansion are adopted in the paper.

$$
\begin{aligned}
& \text { Response coefficient of an industry }=\frac{\mathrm{n} \sum_{j} q_{i j}}{\sum_{i} \sum_{j} q_{i j}} \quad \text { (1) Influence } \\
& \text { coefficient of an industry }=\frac{\mathrm{n} \sum_{i} q_{i j}}{\sum_{i} \sum_{j} q_{i j}} \\
& \text { coefficient }=\frac{V_{j}+M_{j}}{X_{j}} \\
& \text { of economic benefit }=\frac{N_{j}}{X_{j}} \\
& \text { Coefficient of Labor input structure }=\frac{V_{j}}{X_{j}} \\
& \text { Coefficient of industrial expansion }=\frac{N_{j}}{\sum_{i=1}^{n} N_{j}}
\end{aligned}
$$


Among them, $q_{i j}$ is the element of Leontief inverse matrix $(I-A)^{-1}, X_{j}$ represents the total output, which is equal to the total input; $V_{j}$ is the labor remuneration from the input-output table; $M_{j}$ is the operating surplus; $N_{j}$ is the increased value from the input-output table, and these values can be directly obtained from the gross added value part of the third quadrant in the input-output table. [1]

The influence coefficient, response coefficient, technical coefficient, coefficient of economic benefit, coefficient of labor input structure, and coefficient of industrial expansion are synthetically used, as well as the subjective weighting method to calculate the score of comprehensive index, and the index weighting scheme is referenced to that of Li Chongyang, which is as follows: the weighting coefficient of influence coefficient is 0.19 , the weighting coefficient of response coefficient is 0.18 , the weighting coefficient of technical coefficient is 0.15 , the weighting coefficient of the coefficient of economic benefit coefficient is 0.22 , the weighting coefficient of the coefficient of labor input structure is 0.10 , and the weighting coefficient of the coefficient of industrial expansion is 0.16 . The scores of comprehensive indexes of various sectors in Beijing by calculation are shown in table 1. 
Table 1 The calculated score table of comprehensive indexes of various industries in Beijing

\begin{tabular}{|c|c|c|c|c|c|c|c|}
\hline industry & $\begin{array}{l}\text { response } \\
\text { coefficient }(0.18)\end{array}$ & $\begin{array}{l}\text { influence } \\
\text { coefficient } \\
(0.19)\end{array}$ & $\begin{array}{l}\text { technical } \\
\text { coefficient } \\
(0.15)\end{array}$ & $\begin{array}{l}\text { coefficient } \\
\text { of economic } \\
\text { benefit }(0.22 \\
\text { ) }\end{array}$ & $\begin{array}{l}\text { coefficient of } \\
\text { Labor input } \\
\text { structure } \\
(0.10)\end{array}$ & $\begin{array}{l}\text { coefficient of } \\
\text { industrial } \\
\text { expansion } \\
(0.16)\end{array}$ & $\begin{array}{l}\text { total } \\
\text { coefficie } \\
\text { nt }\end{array}$ \\
\hline $\begin{array}{l}\text { Product and service of } \\
\text { agriculture, forestry, } \\
\text { animal husbandry and } \\
\text { fishery }\end{array}$ & 0.9472 & 0.8536 & 0.3156 & 0.3795 & 0.2597 & 0.0084 & 0.4908 \\
\hline Coal mining products & 2.7716 & 2.3273 & 0.0389 & 0.0561 & 0.0178 & 0.0030 & 0.9615 \\
\hline $\begin{array}{l}\text { Extraction products of Oil } \\
\text { and gas }\end{array}$ & 1.2480 & 0.4549 & 0.6028 & 0.7634 & 0.0908 & 0.0002 & 0.5786 \\
\hline Metal mining products & 0.5626 & 1.2395 & 0.0928 & 0.1485 & 0.1056 & 0.0017 & 0.3942 \\
\hline $\begin{array}{l}\text { Non-metallic minerals and } \\
\text { other mining products }\end{array}$ & 0.4122 & 0.7717 & 0.2984 & 0.4713 & 0.2985 & 0.0072 & 0.4003 \\
\hline Food and tobacco & 0.7505 & 1.0360 & 0.0907 & 0.1761 & 0.0807 & 0.0101 & 0.3940 \\
\hline Textile & 0.9073 & 1.2303 & 0.0710 & 0.1041 & 0.0525 & 0.0003 & 0.4359 \\
\hline $\begin{array}{l}\text { Textile clothing, footwear, } \\
\text { leather, down feather and } \\
\text { its products }\end{array}$ & 0.3712 & 1.0590 & 0.2085 & 0.2646 & 0.1328 & 0.0037 & 0.3714 \\
\hline $\begin{array}{l}\text { Wood processed goods and } \\
\text { furniture }\end{array}$ & 0.5655 & 1.1593 & 0.1182 & 0.1729 & 0.0991 & 0.0012 & 0.3879 \\
\hline $\begin{array}{l}\text { Papermaking and printing, } \\
\text { stationery and sporting } \\
\text { goods }\end{array}$ & 1.1271 & 1.1081 & 0.1678 & 0.2370 & 0.1066 & 0.0048 & 0.5021 \\
\hline $\begin{array}{l}\text { Petroleum, coking products } \\
\text { and nuclear fuel processed } \\
\text { products }\end{array}$ & 1.0567 & 0.7294 & 0.0469 & 0.1560 & 0.0143 & 0.0072 & 0.3727 \\
\hline chemical product & 2.6278 & 0.8755 & 0.2413 & 0.3238 & 0.1040 & 0.0270 & 0.7615 \\
\hline $\begin{array}{l}\text { Non-metallic mineral } \\
\text { products }\end{array}$ & 0.6562 & 1.1160 & 0.1263 & 0.1875 & 0.0849 & 0.0061 & 0.3998 \\
\hline $\begin{array}{l}\text { Metal smelting and } \\
\text { calendaring processed } \\
\text { products }\end{array}$ & 5.0153 & 1.5702 & 0.0340 & 0.0766 & 0.0324 & 0.0015 & 1.2265 \\
\hline metal products & 0.7116 & 1.4037 & 0.1126 & 0.1647 & 0.0736 & 0.0039 & 0.4559 \\
\hline General equipment & 0.9657 & 1.2248 & 0.1321 & 0.1905 & 0.1068 & 0.0074 & 0.4801 \\
\hline Special equipment & 0.5538 & 1.2194 & 0.1226 & 0.1735 & 0.1355 & 0.0060 & 0.4024 \\
\hline Transportation equipment & 0.6931 & 1.1467 & 0.1190 & 0.1915 & 0.0495 & 0.0345 & 0.4131 \\
\hline $\begin{array}{l}\text { Electrical machinery and } \\
\text { equipment }\end{array}$ & 0.8208 & 1.2697 & 0.1118 & 0.1538 & 0.0767 & 0.0072 & 0.4484 \\
\hline $\begin{array}{l}\text { Communications } \\
\text { equipment, computers and } \\
\text { other electronic equipment }\end{array}$ & 1.8022 & 1.3274 & 0.0651 & 0.1079 & 0.0541 & 0.0149 & 0.6179 \\
\hline Instrumentations & 0.5264 & 1.1485 & 0.1685 & 0.2148 & 0.1143 & 0.0033 & 0.3975 \\
\hline $\begin{array}{l}\text { Other manufactured } \\
\text { products }\end{array}$ & 0.3144 & 1.1977 & 0.1344 & 0.2041 & 0.1553 & 0.0008 & 0.3649 \\
\hline $\begin{array}{l}\text { Waste products and } \\
\text { materials }\end{array}$ & 0.3903 & 0.5276 & 0.6622 & 0.6711 & 0.0231 & 0.0009 & 0.4199 \\
\hline $\begin{array}{l}\text { Metal products, machinery } \\
\text { and equipment repair } \\
\text { services }\end{array}$ & 0.7265 & 0.9241 & 0.2739 & 0.3697 & 0.2664 & 0.0010 & 0.4556 \\
\hline $\begin{array}{l}\text { The production and supply } \\
\text { of electricity, heating power }\end{array}$ & 3.1524 & 1.4474 & 0.0465 & 0.1420 & 0.0308 & 0.0276 & 0.8882 \\
\hline Gas production and supply & 0.4627 & 0.7439 & 0.1004 & 0.1273 & 0.0586 & 0.0017 & 0.2738 \\
\hline $\begin{array}{l}\text { Water production and } \\
\text { supply }\end{array}$ & 0.3070 & 0.9627 & 0.1773 & 0.3113 & 0.1999 & 0.0010 & 0.3534 \\
\hline Constructions & 0.4441 & 1.2323 & 0.1161 & 0.1840 & 0.1003 & 0.0428 & 0.3888 \\
\hline Wholesale and Retail & 1.9475 & 0.5937 & 0.3429 & 0.5646 & 0.2168 & 0.1247 & 0.6807 \\
\hline $\begin{array}{l}\text { Transportation, } \\
\text { warehousing and postal } \\
\text { services }\end{array}$ & 1.9552 & 0.8876 & 0.1416 & 0.2566 & 0.1476 & 0.0457 & 0.6203 \\
\hline $\begin{array}{l}\text { Accommodation and } \\
\text { catering }\end{array}$ & 0.6163 & 0.8936 & 0.2258 & 0.3128 & 0.2143 & 0.0209 & 0.4082 \\
\hline
\end{tabular}




\begin{tabular}{|l|l|l|l|l|l|l|l|}
\hline $\begin{array}{l}\text { Information transmission, } \\
\text { software and information } \\
\text { technology services }\end{array}$ & 0.5432 & 0.7621 & 0.3919 & 0.5102 & 0.2741 & 0.0904 & 0.4555 \\
\hline Finance & 1.3912 & 0.5406 & 0.5500 & 0.6373 & 0.1751 & 0.1427 & 0.6162 \\
\hline Real estate & 0.5992 & 0.5888 & 0.2817 & 0.5941 & 0.1655 & 0.0696 & 0.4204 \\
\hline $\begin{array}{l}\text { Leasing and business } \\
\text { services }\end{array}$ & 1.4035 & 0.6478 & 0.4277 & 0.5490 & 0.4368 & 0.0742 & 0.6162 \\
\hline $\begin{array}{l}\text { Scientific research and } \\
\text { technical services }\end{array}$ & 0.5935 & 0.8909 & 0.2804 & 0.3523 & 0.2335 & 0.0713 & 0.4304 \\
\hline $\begin{array}{l}\text { Water conservancy, } \\
\text { environment and public } \\
\text { facilities management }\end{array}$ & 0.3414 & 0.8859 & 0.2688 & 0.3345 & 0.2374 & 0.0057 & 0.3683 \\
\hline $\begin{array}{l}\text { Residents services, repairs } \\
\text { and other services }\end{array}$ & 0.4063 & 0.8384 & 0.3547 & 0.4301 & 0.3453 & 0.0070 & 0.4159 \\
\hline Education & 0.3352 & 0.6385 & 0.5210 & 0.5950 & 0.5078 & 0.0383 & 0.4476 \\
\hline Health and social work & 0.2750 & 0.8982 & 0.3053 & 0.3334 & 0.3003 & 0.0202 & 0.3725 \\
\hline $\begin{array}{l}\text { Culture, sports and } \\
\text { entertainment }\end{array}$ & 0.4076 & 0.8357 & 0.2751 & 0.3698 & 0.2494 & 0.0225 & 0.3833 \\
\hline $\begin{array}{l}\text { Public administration, social } \\
\text { security and social } \\
\text { organization }\end{array}$ & 0.2949 & 0.7913 & 0.3393 & 0.3838 & 0.3392 & 0.0318 & 0.3778 \\
\hline
\end{tabular}

The total coefficient of metal smelting, calendaring products (1.2265), coal mining and mining products (0.9615), production and supply of electricity and heat (0.8882), chemical products (0.7615), wholesale and retail (0.6807)and others are larger, of which metal smelting and calendaring products has the highest score in the second industry and is ranked the first, the wholesale and retail industry has highest score in the third industry and is ranked the fifth, and there is none of the first industry.[2]

Analysis of industrial competitiveness

Analysis is carried out in the paper by using the proportion of output value and the location quotient. The formula are as follows:

Proportion of an industry $=\frac{\text { The total output value of an industry }}{\text { The total output value of all industries }}$

Location quotient $=$

The proportion of output value of a certain section of a region in the regional total output value

The proportion of output value of the section of the country in the national total output value

The calculated proportion of output value and location quotient are shown in table 2 . 
Table 2 The calculated results of proportion and location quotient of each industry in Beijing

\begin{tabular}{|c|c|c|}
\hline industry & $\begin{array}{l}\text { proportion of an } \\
\text { industry }\end{array}$ & location quotient \\
\hline $\begin{array}{l}\text { Product and service of agriculture, forestry, } \\
\text { animal husbandry and fishery }\end{array}$ & 0.0075 & 0.1350 \\
\hline Coal mining products & 0.0185 & 1.3170 \\
\hline Extraction products of Oil and gas & 0.0001 & 0.0119 \\
\hline Metal mining products & 0.0039 & 0.4983 \\
\hline $\begin{array}{l}\text { Non-metallic minerals and other mining } \\
\text { products }\end{array}$ & 0.0052 & 1.3180 \\
\hline Food and tobacco & 0.0195 & 0.3555 \\
\hline Textile & 0.0010 & 0.0447 \\
\hline $\begin{array}{l}\text { Textile clothing, footwear, leather, down feather } \\
\text { and its products }\end{array}$ & 0.0047 & 0.2546 \\
\hline Wood processed goods and furniture & 0.0023 & 0.2007 \\
\hline $\begin{array}{l}\text { Papermaking and printing, stationery and } \\
\text { sporting goods }\end{array}$ & 0.0069 & 0.3760 \\
\hline $\begin{array}{l}\text { Petroleum, coking products and nuclear fuel } \\
\text { processed products }\end{array}$ & 0.0157 & 0.6276 \\
\hline chemical product & 0.0284 & 0.3753 \\
\hline Non-metallic mineral products & 0.0110 & 0.3796 \\
\hline $\begin{array}{l}\text { Metal smelting and calendaring processed } \\
\text { products }\end{array}$ & 0.0065 & 0.0939 \\
\hline metal products & 0.0081 & 0.4043 \\
\hline General equipment & 0.0133 & 0.5037 \\
\hline Special equipment & 0.0117 & 0.6001 \\
\hline Transportation equipment & 0.0613 & 1.5182 \\
\hline Electrical machinery and equipment & 0.0159 & 0.5100 \\
\hline $\begin{array}{l}\text { Communications equipment, computers and } \\
\text { other electronic equipment }\end{array}$ & 0.0471 & 1.1645 \\
\hline Instrumentations & 0.0052 & 1.5123 \\
\hline Other manufactured products & 0.0014 & 0.8902 \\
\hline Waste products and materials & 0.0004 & 0.1672 \\
\hline $\begin{array}{l}\text { Metal products, machinery and equipment repair } \\
\text { services }\end{array}$ & 0.0010 & 1.6160 \\
\hline $\begin{array}{l}\text { The production and supply of electricity, heating } \\
\text { power }\end{array}$ & 0.0661 & 2.1732 \\
\hline Gas production and supply & 0.0044 & 2.2821 \\
\hline Water production and supply & 0.0011 & 1.0263 \\
\hline Constructions & 0.0792 & 0.9148 \\
\hline Wholesale and Retail & 0.0752 & 1.6693 \\
\hline Transportation, warehousing and postal services & 0.0606 & 1.5660 \\
\hline Accommodation and catering & 0.0227 & 1.5589 \\
\hline $\begin{array}{l}\text { Information transmission, software and } \\
\text { information technology services }\end{array}$ & 0.0603 & 3.8508 \\
\hline Finance & 0.0762 & 2.0690 \\
\hline Real estate & 0.0399 & 1.5241 \\
\hline Leasing and business services & 0.0460 & 2.1415 \\
\hline Scientific research and technical services & 0.0689 & 4.4235 \\
\hline $\begin{array}{l}\text { Water conservancy, environment and public } \\
\text { facilities management }\end{array}$ & 0.0058 & 1.4986 \\
\hline Residents services, repairs and other services & 0.0056 & 0.5655 \\
\hline Education & 0.0219 & 1.5931 \\
\hline
\end{tabular}




\begin{tabular}{|l|r|r|}
\hline Health and social work & 0.0206 & 1.5899 \\
\hline Culture, sports and entertainment & 0.0207 & 4.7418 \\
\hline $\begin{array}{l}\text { Public administration, social security and social } \\
\text { organization }\end{array}$ & 0.0282 & 1.3415 \\
\hline
\end{tabular}

The industries with higher proportion of output value in Beijing are building (0.0792) , finance (0.0762), wholesale and retail (0.0752), scientific research and technical services (0.0689), production and supply of electricity, heat (0.0661)and others, of which the third industries have the largest proportion, with the stronger absolute competitiveness in Beijing.[3]

The table shows that the number of industries in Beijing with location quotient larger than 1 are 22, while the top 5 are culture, sports and entertainment (4.7418), scientific research and technical services (4.4235), information transmission, software and information technology services (3.8508), gas production and supply (2.1732), and leasing and business services (2.1415), and there are 7 industries with the location quotient larger than 2, and 3 industries with the location quotient larger than 3 , and the location quotients of culture, sports and entertainment are larger than 4 , which indicates that they have the very strong competitiveness. It can be found that the vast majority of these industries are the third industries, which shows the relatively strong competitiveness of the third industry in Beijing.

\section{Conclusion of empirical research}

According to the above analysis, it shows that the response coefficient and influence coefficient of metal smelting and calendaring products, coal mining products, the production and supply of electricity, heat, communication equipment, computers and other electronic equipment, paper making, printing and stationery, and sports goods are larger than 1, which have the sensitive response to the increasing speed of economy, and are in the strategic position, with the top 11 in the ranking of total coefficient; but in terms of the location quotient, the values of paper making, printing, goods of education and sports, metal smelting and calendaring products are smaller, which are not suitable to be the leading industries, while the location quotients of production and supply of electricity and heat, coal mining and selecting products, communication equipment, computers and other electronic equipment, are larger than 1 , which have the relative competitive advantage, and can be selected as the leading industries; but these industries are traditional industries, some other industry should be selected as a supplement.[4]

The location quotients of culture, sports and entertainment are very large, which have the relatively strong competitive advantage of location, compared with that of other places in the country. Beijing is the center of scientific research, and has the higher location quotient and proportion of output value of scientific research and technical services, with the obvious competitive advantage. Furthermore, finance, wholesale and retail, leasing and business service industry have the larger response coefficient, with the top 10 in the ranking of total coefficient, and their location quotient and proportion of output value are also in the top 10, with the larger developing potential, which are suitable as the leading industries.

To sum up, the production and supply of electricity and heat , communications equipment, computers and other electronic equipment, culture, sports and entertainment, scientific research and technical services, finance, wholesale and retail, leasing and business services and the exploring industry of coal mining can be selected as the leading industries.[5]

\section{References}

[1] Rostow, stages of economic growth: a non Communist Manifesto [M], Beijing, University Press, 1962

[2] Su Jin, industrial economics [M], Beijing: Higher Education Press, 2006 
[3] Chenery H B . Patterns of industrial growth [J],The American Economic Review, 1960,50(4):624-654.

[4] Lutkenhorst W. New technologies, and industrialization prospects of developing countries [J]. Intereconomics ,2002

[5] Zhang Zhiying, industrial association analysis and the selection of leading industries in China [J]. Shanghai statistics, 2000, (3) 